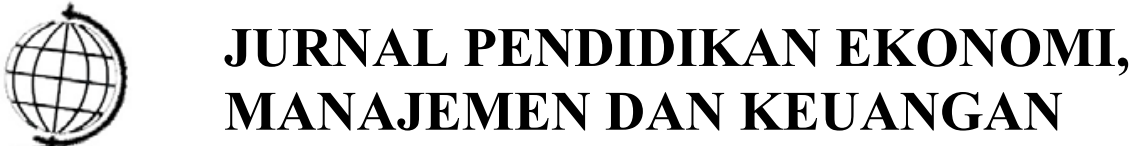

JPEKA Vol. 2 No. 2 November 2018

DOI: $10.26740 /$ jpeka.v6n2.p107-114

\title{
Pengaruh Sosialisasi Keuangan Keluarga Terhadap Perilaku Menabung Mahasiswa
}

\author{
Bima Harya Putra \\ SMA Muhammadiyah 1 Bojonegoro, \\ bimaharyaputra10@gmail.com
}

\begin{abstract}
Abstrak
Penelitian ini bertujuan untuk mendeskripsikan pengaruh sosialisasi keuangan keluarga terhadap perilaku menabung mahasiswa. Populasi penelitian ini yaitu mahasiswa fakultas ekonomi uniersitas negeri Surabaya. Teknik sampling yang digunakan dalam penelitian ini adalah purposive sampling dan besar sampel adalah 264 responden. Metode angket dipilih untuk pengumpulan data. Untuk memproses data digunakan regresi linier. Hasil dari analisis data yaitu sosialisasi keuangan keluarga berpengaruh positif signifikan terhadap perilaku menabung mahasiswa.
\end{abstract}

Kata Kunci: Sosialisasi, Keuangan, Perilaku Menabung.

\begin{abstract}
The research to analyze the effect of family financial socialization on saving behavior. The population is all college students of economic faculty of Universitas Negeri Surabaya who already get the socialization of financial in the family. 264 respondents were selected using purposive random sampling. The questionnaire had selected to used data collection. The data analysis using linear regression. The results of data analysis is a positive effect of family financial socialization on saving behavior collage students of economic faculty of Universitas Negeri Surabaya.

Keywords: Sosialization, Finance, Saving Behaviour.
\end{abstract}

\section{PENDAHULUAN}

Indikator makro ekonomi negara berkembang salah satunya adalah pertumbuhan ekonomi. Untuk mendorong pertumbuhan ekonomi, salah satu cara adalah meningkatkan nilai tabungan. Saat ini, Bank Indonesia selaku bank sentral negara Indonesia berusaha menumbuhkan budaya menabung masyarakat Indonesia. Salah satu usaha Bank Indonesia dalam menumbuhkan budaya menabung masyarakat Indonesia adalah dengan mengeluarkan produk-produk tabungan untuk perorangan dengan syarat yang mudah dan ringan. Selain Bank Indonesia, lembaga keuangan lain yang berperan dalam menumbuhkan budaya menabung masyarakat Indonesia adalah Otoritas Jasa Keuangan (OJK). Dalam menumbuhkan budaya menabung masyarakat Indonesia khususnya generasi muda, OJK bersama dengan perbankan mengembangkan produk tabungan bagi para pelajar yang diberi nama Simpanan Pelajar. Dengan adanya produk ini diharapkan agar dapat menjadikan kegiatan menabung sebagai kebutuhan gaya hidup bukan sebagai kewajiban. 
Berdasarkan studi hasil praobservasi dari 30 mahasiswa Fakultas Ekonomi Universitas Negeri Surabaya, 30 mahasiswa yang dijadikan objek praobservasi memiliki rekening di bank. 27 dari 30 mahasiswa menyimpan (menabung) dari sebagian pendapatn mereka tiap bulan. Dapat disimpulkan bahwa budaya menabung di Fakultas Ekonomi Universitas Negeri Surabaya dapat dikatakan baik.

Mahasiswa dapat dikategorikan sebagai masa akhir remaja, karena mahasiswa berumur sekitar 18-20 tahun. Hal ini budaya/kebiasaan yang diajarkan orang tua masih terikat oleh mahasiswa. Bagi sebagian dari mereka, menjadi mahasiswa merupakan pertama kalinya mereka mengalami kemandirian finansial tanpa pengawasan orangtua. Oleh karena itu, pengetahuan tentang keuangan yang diperoleh/diajarkan dari orang tua dapat membantu mereka dalam mengelola keuangan pribadi. Karena pada masa kuliah mahasiswa belum memiliki pendapatan sehingga sering terjadi permasalahan terkait dengan pengelolaan keuangan karena uang yang dimiliki berjumlah terbatas (Nababan dan Sadalia, 2013). Orang tua sangat berpengaruh dalam mengembangkan perilaku keuangan anak-anak mereka. Orang tua menjadi model atau contoh anak-anak mereka dalam mengelola keuangan. Webley dan Nyhus (2006) menyatakan bahwa sosialisasi ekonomi (yaitu yang membahas masalah keuangan dengan orang tua) akan memberi dampak pada orientasi masa depan anak. Ketika orang tua menampilkan perilaku keuangan yang positif, mereka akan menjadi panutan untuk anak-anak dan akan memicu sikap positif dan perilaku yang baik dalam kegiatan keuangan mereka. Sosialisasi keuangan melampaui pengetahuan keuangan untuk memasukkan faktor-faktor seperti sikap, keyakinan, peran, keterampilan, dan nilai-nilai (Danes, 1994). Norvitilis dan Maclean (2010) berpendapat bahwa masa kanak-kanak adalah masa paling penting yang akan mempengaruhi perilaku dan sikap individu selama masa dewasa. Peran Orang tua sangat penting untuk mempengaruhi anak-anak dalam mengelola urusan keuangan mereka. Berdasarkan uraian diatas, peneliti tertarik untuk mengetahui pengaruh sosialisasi keuangan keluarga terhadap perilaku menabung mahasiswa Fakultas Ekonomi Universitas Negeri Surabaya.

Menurut Bowen (2002) sosialisasi keuangan adalah proses belajar untuk memperoleh pengetahuan tentang uang dan pengelolaan uang dan mengembangkan keterampilan dalam berbagai praktik keuangan seperti perbankan, penganggaran, tabungan, asuransi, penggunaan kartu kredit. Danes (1994) menyatakan bahwa sosialisasi keuangan adalah proses memperoleh dan mengembangkan nilai-nilai, sikap, standar, norma, pengetahuan, dan perilaku yang berkontribusi untuk mengelola keuangan dan kesejahteraan individu.

Karakteristik keluarga mempengaruhi pola komunikasi tentang keuangan yang mengarah ke perilaku keuangan yang baik. Beutler dan Dickson (dalam Gudmunson, 2011) telah memberikan pandangan yang komprehensif tentang bagaimana anggota keluarga mempengaruhi hasil antara seperti pengembangan sikap keuangan (misalnya materialisme, kehati-hatian keuangan) yang memiliki kaitan dengan perilaku keuangan dan kesejahteraan.

Grusec dan Davidov (dalam Shin, 2010) telah mengemukakan lima alasan orang tua terlibat dalam sosialisasi, (1) orang tua tidak hanya untuk menghasilkan keturunan, tapi untuk ada tuntutan terhadap pola asuhan mereka, (2) orang tua yang prima untuk melindungi dan menjaga anak-anak ketika bermain menjadi kebutuhan yang saling berkaitan, (3) ada harapan budaya yang kuat di semua masyarakat untuk orang tua menjadi pelaku sosialisasi utama anak-anak, (4) karena orang tua biasanya tinggal di dekat anak-anak mereka, ada sebuah insentif bagi orang tua untuk membantu membangun perilaku prososial pada anak-anak, dan (5) orang tua mengontrol 
sumber daya ekonomi dan materi yang dibutuhkan anak-anak dalam tumbuh dan berkembang.

Gudmunson (2011) menggambarkan interaksi dan hubungan keluarga sangat penting karena pandangan holistik dari sosialisasi keuangan mengakui bahwa pola interaksi antara anggota keluarga mempengaruhi perkembangan sikap keuangan, transfer pengetahuan, dan pengembangan kemampuan keuangan. Moschis (1985) mengidentifikasi tiga cara belajar terjadi dalam keluarga yaitu 1) komunikasi sadar atau tidak sadar dari norma-norma dan harapan yang dihasilkan dari pengamatan atau imitasi dari perilaku, 2) penguatan positif dan negatif anggota keluarga, dan 3) komunikasi terbuka. Keberhasilan orang tua dalam mempromosikan nilai-nilai ini melalui pengalaman menabung bisa tergantung pada kualitas hubungan orang tua dengan anak. Anak-anak yang merasa bahwa orang tua yang penuh kasih dan hangat, yang secara rutin menghabiskan waktu dengan orang tua, atau memiliki komunikasi positif dengan orang tua lebih mungkin untuk berbagi nilai-nilai prososial orang tua tentang uang (Kim, et al. 2011).

Sikap keuangan, pengetahuan keuangan, dan kemampuan keuangan merupakan hasil dari perantara sosialisasi keuangan (Gudmunson, 2011). Ward (1974) menyatakan bahwa sosialisasi berfokus pada sikap, pengetahuan, dan keterampilan. Sedangkan Dalam pandangan Gudmunson (2011), kemampuan merupakan konsep yang lebih luas dari pada keterampilan. Kemampuan bersudut pandang apa yang mengembangkan individu untuk mampu melakukan, sedangkan keterampilan bersudut pandang yang menekankan apa yang dilakukan adalah kemahiran. Produk akhir dari sikap keuangan, pengetahuan, dan kemampuan keuangan adalah perilaku keuangan dan kesejahteraan keuangan (Gudmunson, 2011).

Ada dua jenis perilaku keuangan yang saling terkait. Pertama dan yang paling umum, adalah pola tindakan dari waktu ke waktu seperti menabung, melakukan pengeluaran, dan gifting. Tipe kedua yang tidak kalah penting untuk keberhasilan keuangan, berkaitan dengan titik balik keuangan dan pengambilan keputusan. Membangun kesejahteraan keuangan meliputi indikator objektif dan subjektif. Contoh indikator objektif meliputi pendapatan dan tingkat tabungan, kepemilikan barang, rasio keuangan, dan laporan kredit yang dapat dipercaya. Sedangkan indikator subjektif didasarkan pada perspektif individu dan opini. Contoh indikator subjektif seperti kepuasan keuangan, tekanan ekonomi yang rendah, kecukupan penghasilan, dan sebagainya.

Dalam Theory Of Planned Behavior (TPB), Ajzen (2002) berpandangan bahwa keyakinan perilaku menghasilkan sikap terhadap perilaku, keyakinan normatif mengakibatkan normanorma subjektif dan keyakinan kontrol menghasilkan dirasakan kontrol perilaku. Kombinasi dari semua unsur-unsur ini mengarah pada pembentukan niat perilaku. Niat merupakan motivasi rencana sadar individu untuk mengerahkan usaha untuk melakukan behavior tersebut. Ajzen (1991) membedakan jenis-jenis keyakinan yaitu behavior belief merupakan keyakinan akan hasil perilaku dan mngevaluasi hasil tersebut sehingga akan mempengaruhi sikap terhadap perilaku. Normative belief merupakan keyakinan terhadap harapan normatif orang lain yang menjadi rujukannya. Control belief merupakan keyakinan individu terkait keberadaan hal-hal yang menghambat ataupun mendukung perilaku serta persepsinya tentang seberapa kuat hal-hal yang mempengaruhi perilakunya.

Menurut Bank Indonesia (2010) Menabung merupakan kegiatan menyisihkan uang untuk mencapai target dana tertentu supaya bisa dipakai untuk tujuan tertentu di masa depan. Perilaku menabung merupakan suatu perilaku yang dilakukan seseorang dengan menyisihkan sebagian pendapatannya untuk disimpan dan digunakan di masa depan (Bank Indonesia, 2010). Menurut 
Ada delapan motif yang berbeda dalam menabung antara lain Precaution (tindakan pencegahan), Foresight (tinjauan masa depan), Calculation (perhitungan), Improvement (perbaikan), Independence (kebebasan), Enterprise (usaha), Pride (kebanggaan), Avarice (keserakahan harta) (Keynes, 1936). Daya menabung masyarakat dipengaruhi oleh (1) Kesanggupan menabung (ability to save) dan (2) Kemauan menabung (willingness to save).

\section{METODE}

Penelitian ini menggunakan pendekatan penelitian kuantitatif. Dalam penelitian ini, pendekatan kuantitatif digunakan untuk mendeskripsikan fakta-fakta suatu populasi secara faktual dan sistematis tentang pengaruh kontrol diri, sosialisasi keuangan keluarga, dan literasi keuangan terhadap perilaku menabung mahasiswa fakultas Ekonomi Universitas Negeri Surabaya.

Populasi penelitian ini yaitu mahasiswa Fakultas Ekonomi Universitas Negeri Surabaya angkatan 2015. Mahasiswa Fakultas Ekonomi Universitas Negeri Surabaya angkatan 2015 dijadikan populasi karena mahasiswa angkatan 2015 dapat dikategorikan sebagai masa remaja akhir. Banyak sampel yang digunakan dalam penelitian berdasarkan perhitungan di atas adalah 264 dari 780 populasi. Teknik sampling yang digunakan adalah purposive sampling. Sampel penelitian ini adalah mahasiswa angkatan 2015/2016 yang telah mendapatkan sosialisasi keuangan keluarga.

Penelitian ini menggunakan metode pengumpulan data berupa metode angket. Sedangkan untuk mengetahui pengaruh sosialisasi keuangan keluarga terhadap perilaku menabung mahasiswa, penelitian ini menggunakan analisis regresi.

\section{HASIL DAN PEMBAHASAN}

Data variabel sosialisasi keuangan keluarga dalam penelitian ini diambil dari hasil angket yang telah dibagikan kepada responden. Hasil kuesioner pada variabel sosialisasi keuangan keluarga dapat dilihat pada tabel berikut.

Tabel 1. Hasil Kuesioner Variabel Sosialisasi Keuangan

\begin{tabular}{cll}
\hline Class Interval & $\mathbf{F}$ & $\mathbf{\%}$ \\
\hline $41-45$ & 55 & 20,83 \\
$36-40$ & 120 & 45,45 \\
$31-35$ & 71 & 26,89 \\
$25-30$ & 18 & 6,82 \\
\hline Total & $\mathbf{6 2}$ & $\mathbf{1 0 0}$ \\
\hline
\end{tabular}

Sumber: data diolah (2017)

Berdasarkan hasil analisis regresi dari sosialisasi keuangan keluarga terhadap perilaku menabung mahasiswa dengan bantuan SPSS 16.0 for windows dapat dideskripsikan bahwa berdasarkan hasil uji t, diperoleh nilai t hitung sebesar 5.960 dengan nilai signifikansi t sebesar 0,000. Karena nilai t hitung $5.960>\mathrm{t}$ tabel 1.96913, maka dapat disimpulkan bahwa sosialisasi keuangan keluarga berpengaruh secara positif signifikan terhadap perilaku menabung mahasiswa Fakultas Ekonomi Universitas Negeri Surabaya. Tabel hasil uji regresi dapat dilihat pada tabel 2. 
Tabel 2. Hasil Uji Regresi

\begin{tabular}{|c|c|c|c|c|c|}
\hline \multicolumn{6}{|l|}{ Coefficients $^{\mathbf{a}}$} \\
\hline & \multicolumn{2}{|c|}{$\begin{array}{c}\text { Unstandardized } \\
\text { Coefficient }\end{array}$} & \multicolumn{2}{|c|}{$\begin{array}{c}\text { Standardized } \\
\text { Coefficients }\end{array}$} & \\
\hline \multicolumn{5}{|c|}{ Error } & sigt \\
\hline 1 (Constant) & 6.920 & 3.319 & & 2.085 & .038 \\
\hline $\begin{array}{l}\text { Sosialisasi } \\
\text { Keuangan } \\
\text { keluarga }\end{array}$ & .347 & .058 & .333 & 5.960 & .000 \\
\hline $\begin{array}{l}\text { a. Dependent } \\
\text { Perilaku men }\end{array}$ & $\begin{array}{l}\text { Variabl } \\
\text { abung }\end{array}$ & & & & \\
\hline
\end{tabular}

\section{Pengaruh Sosialisasi Keuangan Keluarga terhadap Perilaku Menabung}

Sosialisasi keuangan adalah proses memperoleh serta mengembangkan nilai-nilai, sikap, standar, norma, pengetahuan, dan perilaku yang berkontribusi untuk mengelola keuangan dan kesejahteraan individu (Danes, 1994). Keluarga, khususnya orang tua mempunyai peran penting dalam pendidikan keuangan anak. Karena orang tua biasanya tinggal di dekat anak-anak mereka, ada sebuah insentif bagi orang tua untuk membantu membangun perilaku prososial pada anakanak. Hal ini sejalan dengan temuan penelitian ini bahwa Mayoritas mahasiswa Fakultas Ekonomi Universitas Negeri Surabaya menganggap orang tua merupakan contoh yang baik bagi mereka ketika melakukan manajemen uang. Mahasiswa juga senang berdiskusi tentang pengelolaan keuangan dengan orang tua. Pengaruh keluarga dianggap sebagai faktor yang paling kuat dan signifikan dalam membentuk perilaku menabung anak.

Temuan lain adalah mayoritas mahasiswa berpendapat bahwa orang tua akan merasa bangga jika mereka menabung. Mereka juga menghargai saran dari orang tua tentang apa yang harus mereka lakukan dengan uang mereka. Selain itu, mahasiswa menyimpan uang karena mereka berpikir bahwa orang tua tidak harus membayar untuk hal-hal yang tidak benar-benar perlu, misalnya kebutuhan pribadi mereka. Dalam hal proteksi, orang tua mahasiswa selalu mengajarkan membeli barang yang bermanfaat dan melarang mereka untuk berhutang. Temuan lain adalah banyak juga dari mahasiswa tidak setuju jika orang tua ikut mengontrol pengeluaran mereka. Selian itu, banyak mahasiswa yang tidak setuju jika orang tua untuk tetap memegang uang mereka.

Hasil penelitian ini didukung oleh oleh penelitian yang dilakukan Mischel (1961) membuktikan bahwa orang tua yang memberi pengetahuan dan skill menabung akan memengaruhi perilaku menabung anak-anak mereka. Hal ini sejalan dengan penelitian Sulaeman (2012) yang menyatakan bahwa orang tua adalah sumber dari pengetahuan tentang pengelolaan keuangan pribadi anak. Oleh karena itu orang tua harus menjadi teladan serta memberikan contoh kepada anak dalam mengelola keuangan pribadi yang baik. Sehingga diharapkan akan memicu sikap keuangan dan perilaku keuangan yang positif pada anak-anak. 


\section{PENUTUP}

\section{Simpulan}

Sosialisasi keuangan keluarga berpengaruh positif terhadap perilaku menabung mahasiswa Fakultas Ekonomi Universitas Negeri Surabaya. Hal ini menunjukkan bahwa semakin banyak sosialisasi keuangan yang diterima mahasiswa dari keluarga maka semakin baik pula perilaku menabung mahasiswa. Temuan pada penelitian ini adalah Mayoritas mahasiswa menganggap orang tua merupakan contoh yang baik bagi mereka ketika melakukan manajemen uang. Mahasiswa juga senang berdiskusi tentang pengelolaan keuangan dengan orang tua. Pengaruh keluarga dianggap sebagai faktor yang paling kuat dan signifikan dalam membentuk perilaku menabung anak. Temuan lain adalah mayoritas mahasiswa berpendapat bahwa orang tua akan merasa bangga jika mereka menabung.

\section{Saran}

Untuk meningatkan aktivitas menabung mahasiswa hendaknya mahasiswa berdiskusi dengan orang tua. Dengan adanya diskusi diharapkan orang tua dapat memberikan saran kepada mahasiswa terkait dengan pengelolaan keuangan mereka.

\section{DAFTAR PUSTAKA}

Ajzen, I. (1991). The Theory Of Planned Behaviour: Organizational Behaviour And Human Decision Processes, Vol. 50

Ajzen, I. (2002). Residual Effect Of Past On Later Behaviour: Habituation And Reasoned Action Perspectives. Personality And Social Psychology Review, Vol. 6, No. 2

Danes, S. M. (1994). Parental Perceptions Of Children's Financial Socialization. Financial Counseling And Planning, Volume 5

Gudmunson, Clinton. (2011). Family Financial Socialization: Theory And Critical Review. Journal of Family And Economic. Volume 32(4) DOI 10.1007/s10834-011-9275-y

Mischel, W. (1961). Father-Absence And Delay Of Gratification: Cross-Cultural \& Comparisons. Journal of Abnormal and Social Psychology. Vol.63

Moschis, G. P. (1985). The Role Of Family Communication In Consumer Socialization \& Children And Adolescents. The Journal Of Consumer Research, Volume 11 (4): 898-913

Nababan, Darman \& Sadalia, Isfenti. (2013). Personal Financial Literacy \& Financial Behaviour Mahasiswa Strata 1 Fakultas Ekonomi Universitas Sumatera Utara. Http://Jurnal.Usu.Ac.Id/Index.Php/Jmim/Article/View/651/Pdf Diakses Pada Tanggal februari 2017. 
OJK. 2016. Survei Nasional Literasi Dan Inklusi Keuangan 2016

Shin, Wonsun. 2010. The Role Of Parental Mediation In Children's Consumer Socialization On The Web. Dissertation Submitted To The Faculty Of The Graduate School Of The University Of Minnesota

Webley, P., \& Nyhus, E. K. 2006. Parents' Influence On Children's Future Orientation And Saving. Journal Of Economic Psychology, Volume 27 
Bima Harya Putra 